\title{
Analysis of the Need for Community-Based Creative Economy Training for the Development of Family Economic Resilience During the Covid-19 Pandemic
}

\author{
Viena R Hasanah*, Hodijah Wulandari \\ Community Education Department \\ Universitas Pendidikan Indonesia \\ Bandung, Indonesia \\ *viena@upi.edu, hodijahw@student.upi.edu
}

\author{
Yoyoh Jubaedah \\ Family Welfare Education Department \\ Universitas Pendidikan Indonesia \\ Bandung, Indonesia \\ yoyohjubaedah@upi.edu
}

\begin{abstract}
Pandemic in Indonesia has prompted the government to implement a large-scale social restriction policy in an effort to break the chain of transmission and protect the population from the risk of transmission. This condition makes the importance of physical (economic) resilience by developing skills in a family friendly environment that can enhance productive culture. Creative Economy is an economic activity that makes creativity the main asset in creating added value to the economy by providing input in the form of education, experience, training, coaching, coaching and direction. This study aims to determine what kind of creative economy training needs will build family economic resilience during this pandemic, particularly for urban poor families. This study uses Design Based Research (DBR). The research approach in the first stage of the DBR design uses a qualitative approach, using interview techniques, observation, documentation study, and FGD (Forum Group Discussion). The research subjects were community leaders, including the village head, PKK cadres and Motekar (Motivator Family Resilience) in the Babakan Sari Village, Kiaracondong District, Bandung City. The results showed that the form of intervention that could be carried out was through creative economy training in which business development was carried out through the use of technology which focused on excellence (1) product packaging design; and (2) online product marketing.
\end{abstract}

Keywords—family empowerment, desain based research

\section{INTRODUCTION}

At the end of last year, the world was shocked by the emergence of a new disease with symptoms similar to influenza. This disease is caused by a virus and spreads rapidly to cause death. Everyday patients with cases of the disease continue to increase to the number of thousands of cases [1].

In its development in early 2020, WHO officially declared that the spread of the virus identified as Novel Coronavirus was a pandemic. The status of a pandemic is declared by WHO because this outbreak has spread in almost all countries in various parts of the world with a high number of cases $[2,3]$.
Likewise, with the state of Indonesia, the virus finally entered Indonesia, announced directly by President Joko Widodo. This has led the government to issue PP No. 21 of 2020 which regulates the Implementation of Large Scale Social Restrictions stipulated by the Minister of Health and carried out by all Regional Governments based on the approval of the Minister of Health. This Large Scale Social Restriction is an effort to break the chain of transmission and protect the population from the risk of transmission [4]. The transmission of this virus has been identified that the transmission can be decided individually by maintaining personal hygiene and in groups through social distancing [5-8]. Social distancing is a way to widen the distance between people in order to reduce the risk of transmission of the virus [9].

The implementation of these regulations has had a huge impact on society in various sectors, especially the economic, education and social sectors. The education sector has made major changes in organizing teaching and learning activities $(\mathrm{KBM})$ at all levels of education into learning from home online. The social sector has also undergone a change in which almost all types of interactions are carried out online. The economic sector has had a tremendous impact on large and small business sectors due to a decrease in purchasing power and consumption in society [10].

This condition certainly greatly affects the poor and increases the poverty rate. In addition, the outbreak and the PSBB policy have had a considerable influence on the physical health and mental health of the community [11], public health and the environment [12], lifestyle and communication [13]. Influences at the individual level, namely depression, anxiety, confusion, fear, and anger that have an impact on the family [14].

The drastic decline in economic conditions will certainly greatly affect various aspects of people's lives, including in the city of Bandung. The number of people affected by the COVID-19 pandemic was 2,150 confirmed cases as of $06 / 11 / 2020$ [15]. 
The number of cases has certainly made the Bandung City Government as a local government to take steps to implement a social restriction policy to prevent an increase in cases. This will certainly affect various aspects of the life of the people of Bandung. Family conditions, social conditions, economic conditions, educational conditions and others will experience changes in conditions from before [16].

Individual resilience in dealing with the COVID-19 outbreak is needed. Various information that comes in through various media will greatly influence a person's perception of COVID-19. Information and prevention methods that are received are those that are fully followed by every individual who is not followed, this can happen because the community does not receive proper information [17]

As for family resilience, which is a dynamic condition of a family that has tenacity and toughness as well as material physical and mental spiritual abilities to live independently and develop themselves and their families to live in harmony and improve physical and mental well-being [18].

The achievement indicators of family resilience include aspects of physical (economic) resilience, social resilience and psychological resilience, using measures through the implementation of family functions, fulfillment of roles and duties, resource management, stress management, and family interactions [19]. Family vulnerability is the family's inability to respond to crisis/conflict/emergency situations [20]. The vulnerability of the family is closely related to how the family can face various threats or disturbances that can disrupt the stability and welfare of the family. This is common in urban poor families [21].

Urban poor families need support in obtaining family income / income, which due to limited knowledge, skills, market access and entrepreneurial mentality, do not have permanent income and are even unemployed so they are vulnerable to family integrity and the quality of family welfare especially during a pandemic like this.

This condition makes the importance of physical (economic) resilience to be built by developing skills and skills as well as family-friendly areas that can increase productive culture. Creative Economy is an economic activity that makes creativity the main capital in creating added value to the economy by providing input in the form of education, experience, training, coaching, guidance and direction.

This study aims to determine what kind of creative economy training needs will build family economic resilience during this pandemic, especially for urban poor families.

\section{METHODS}

This study uses the DBR (Design-Based Research) approach, namely design-based research that is identical to development research [21,22]. DBR is a flexible research approach in improving educational practice with a process of in-depth analysis, designing development and implementation concepts on the basis of collaboration between researchers and practitioners in accordance with the reality. This approach directs research towards contextual-sensitive design principles in accordance with existing theories $[21,23]$.

In general, there are three phases carried out in this development research, namely the preliminary phase, the prototype phase (cycle intervention according to design, and the assessment and reflection phase. In this study, the preliminary phase was carried out through direct interaction with community leaders through FGD activities (Forum Group Discussion). In this stage, an analysis will be carried out to formulate a research problem by considering the needs of the community and the potential conditions of Natural Resources (NR) and Human Resources (HR). Literature reviews and the results of discussions with the community will become an analysis to build a preliminary design framework until entering the next stage, namely the formation of a prototype in the form of a cycle intervention. This paper will examine the preliminary stage, which is to produce an analysis of community needs in building economic resilience during a pandemic. The next stage will be presented in the next study in another paper

The research approach in the first stage to second stage of the DBR design uses a qualitative approach, using interview techniques, observation, documentation study, and FGD (Forum Group Discussion). The research subjects were community leaders, including the village head, PKK cadres and Motekar (Motivator Family Resilience) in the Babakan Sari Village, Kiaracondong District, Bandung City.

\section{FINDINGS AND DISCUSSION}

In the research process, researchers performed several techniques, starting from documentation studies, literature studies, interviews, regional observations, and approaches with community leaders and stakeholders in the Babakan Sari Village, Kiaracondong District, Bandung City.

This research specifically wants to know and analyze what kind of community-based creative economy training needs for the development of family economic resilience during the Covid-19 pandemic.

\section{A. Preliminary Research Phase}

The research team conducted literature studies related to various studies on the concept of family resilience, the concept of community empowerment, as well as various studies on creative economic development in increasing family resilience

The research team also identified the resilience of individuals, families and communities in the area. Based on the results of observations, interviews and forum group discussions, with community leaders and community activists, the economic conditions in this area which is dominated by poor families in Bandung City are very vulnerable to meeting their daily needs. In one RW in the area, more than $60 \%$ of the population is PKH beneficiary, meaning they are the poor who live in urban areas, with densely populated environmental 
conditions and close to railroad banks. Based on the results of observations and interviews, almost half of the population there are migrants from various regions to make a living in urban areas. This condition causes environmental aspects to support community resilience as a challenge. Local governments are demanded to pay more attention, to fulfill physical aspects such as housing, infrastructure, physical environment, economy and income which are still common problems in the region. Meanwhile, from the economic aspect, most people are micro, small and medium enterprises (MSMEs) to save economic resilience for individuals, families and communities.

\section{B. Consultation of Researchers and Practitioners}

One of the most fundamental in determining problems in design-based research is by conducting in-depth consultations between researchers and practitioners. Some experts argue that research will not go well without involving and collaborating closely with practitioners to solve the problem. We recognize close collaboration as the ideal should happen for design-based research / DBR which is sometimes difficult to do. Researchers must go down directly to know the problems that exist together with the team and be involved together with the practitioners who are in determining these common problems.

Open acceptance from residents and community leaders makes it easier for the research team to collaboratively, discuss in-depth about the condition of the community, family conditions, education, livelihoods, income, and culture and environmental conditions that exist there. Various observational studies, interviews with motekar, community leaders, the surrounding community, regarding their hopes and conditions, direct researchers to the problems that exist there.

Delivered by the residents and community leaders of Babakan Sari Village, They hope that there will be a creative economy training model which includes mapping community businesses as a strategy that is developed so that the creation of targeted programs is then given guidance to increase the knowledge and skills of business actors in creating added value products such as in the aspects of product design and packaging as well as opening up opportunities for business actors to expand marketing through online business management to developing access to local governments and other financial institutions for future business plans and for establishing partnerships from various business sectors.

\section{Building a Theoretical Framework}

The theoretical framework for research will be reflected in the literature used to inform this study. This theoretical framework is also the place where the theoretical basis of the proposed solutions will be explained. The theoretical framework is well described, providing a solid basis for the proposed solutions, because theory can inform practical design guidelines. Barab and Squire [24] state that design-based research/DBR demonstrates a pragmatic philosophical foundation, where the value of theory lies in its ability to bring about change in the world.
The theoretical framework used in developing solutions to problems that occur in the empowerment of urban poor families, including theories and concepts regarding family empowerment, group intervention, training and community assistance, creative economic development, and family resilience.

\section{Development of Draft Principles for Leading to Intervention Design}

The draft development principles for intervention design are various directions and principles related to literature review and the various conditions that allow for the preparation of intervention designs. In this research, there are several principles related to the development of family resilience, which are built by physical/economic resilience, social resilience and psychological resilience. The conditions that occur for the characteristics of the urban poor families, of course, the economic aspect is the main obstacle in building family resilience.

This means that the main principle in developing the economy becomes the first stimulation before entering into other aspects. Another principle related to family empowerment is community readiness. Preparation of time and place as well as public awareness are important keys in conveying the message.

This means that there is a need for appropriate and efficient media in developing the program. Another principle is related to the sustainability of the program. There needs to be a sustainable support capacity so that empowerment programs in the community can run well, he follows. It is necessary to build a system and the ease with which this program can run, there also needs to be yeast and the carrying capacity of the spirit in the running of this program and this must be started from the driving figures in the community.

\section{E. Description of the Proposed Intervention}

The proposed solutions to the nominated economic problems are developed from consideration of the relevant literature, consultation and collaboration with researchers and practitioners, and as examples of principles derived from these sources. Intervention design as a solution, this is the second phase, namely the Prototyping phase.

In this phase, the research team prepared the intervention design as a result of the development of existing problems and needs. Based on the results of problem identification through discussions with various parties as well as opportunities and opportunities that might be carried out in the location, economic problems supported by business development through technology utilization for the community are an obstacle to economic problems. For this reason, partnerships are built between the Motekar program, through FGD (Focus Group Discussion) meeting sessions to be supported by creative economy training programs.

Even creative fields that will be developed, are explored from the local potential that is there, with the capacity that is 
already owned, namely businesses in the culinary sector. Researchers use this opportunity to intervene in the form of a creative economy training program for business development through the use of technology.

The creative economy training model carried out is community-based, meaning that as a facilitator uses motekar power, while the presenters involve business partners who have the ability and focus on the field of business development by utilizing technology. This training is based on the results of the field that the business actors in Babakan Sari Village do not have added value to their products because they have not been touched by technology. Therefore, this creative economy training will focus on 2 things, namely (1) product packaging design; and (2) online product marketing.

\section{CONCLUSION}

Analysis of the need for community-based creative economy training for the development of family economic resilience during the Covid-19 pandemic in Babakan Sari Village, Kiaracondong District, Bandung City was carried out through three phases starting from the preliminary phase, the prototype phase and the assessment phase.

The research found that most of the people there are micro, small and medium enterprises (MSMEs) to save economic resilience for individuals, families and the community itself. The results of the needs analysis gave rise to opportunities that were used by researchers to intervene in the form of creative economy training programs for business development through the use of technology which would be focused on 2 things, namely (1) product packaging design; and (2) online product marketing.

\section{ACKNOWLEDGMENT}

Thanks to the Ministry of Research, Technology and Higher Education for funding this research.

\section{REFERENCES}

[1] WHO, World Health Statistic, Monitoring Health for SDGs, sustainable development goals, 2020.

[2] S. Dryhurst, C.R. Schneider, J. Kerr, A.L. Freeman, G. Recchia, A.M. Van Der Bles and S. van der Linden, Risk perceptions of COVID-19 around the world. Journal of Risk Research, vol. 23(7-8), pp. 994-1006, 2020

[3] C. Sohrabi, Z. Alsafi, N. O'Neill, M. Khan, A. Kerwan, A. Al-Jabir, and Agha, R. World Health Organization declares global emergency: A review of the 2019 novel coronavirus (COVID-19). International journal of surgery, vol. 76, pp. 71-76, 2020.

[4] A.A. Pradana, and C. Casman, Pengaruh Kebijakan Social Distancing pada Wabah COVID-19 terhadap Kelompok Rentan di Indonesia. Jurnal Kebijakan Kesehatan Indonesia: JKKI, vol. 9(2), pp. 61-67, 2020.
[5] F.M. Mansuri, Situation analysis and an insight into assessment of pandemic COVID-19. Journal of Taibah University Medical Sciences, vol. $15(2)$, pp. 85,2020

[6] M.Y. Yen, A.H. Chiu, J. Schwartz, C.C. King, Y.E. Lin, S.C. Chang, and P.R. Hsueh, From SARS in 2003 to H1N1 in 2009: lessons learned from Taiwan in preparation for the next pandemic. Journal of Hospital Infection, vol. 87(4), pp. 185-193. 2014.

[7] S. Maharaj, and A. Kleczkowski, Controlling epidemic spread by social distancing: Do it well or not at all. BMC public health, vol. 12(1), pp. 116. 2012.

[8] Y. Zhang, Q. Zhao, and B. Hu, Community-based prevention and control of COVID-19: Experience from China. American journal of infection control, vol. 48(6), pp. 716-717. 2020.

[9] B. Sen-Crowe, M. McKenney, and A. Elkbuli, Social distancing during the COVID-19 pandemic: Staying home save lives. The American journal of emergency medicine, vol. 38(7), pp. 1519-1520. 2020

[10] A.K. Pakpahan, Menyelamatkan Penjualan Ritel di Tengah Pandemi Covid-19. Covid-19 Dan Implikasi Bagi Usaha Mikto, Kecil, Dan Menengan, vol. 1(5), pp. 3870-59. 2020

[11] C.S. Ho, C.Y. Chee, and R.C. Ho, Mental Health Strategies to Combat the Psychological Impact of COVID-19 Beyond Paranoia and Panic Annals of the Academy of Medicine, Singapore, vol. 49(1), pp. 1-3. 2020 .

[12] J. Tsai, and M. Wilson, COVID-19: a potential public health problem for homeless populations. The Lancet Public Health, vol. 5(4), pp. e186e187. 2020.

[13] J.A. Dani, and Y. Mediantara, Covid-19 dan Perubahan Komunikasi Sosial. Persepsi: Communication Journal, vol. 3(1), pp. 94-102. 2020.

[14] M.R. Ramadhana, Mempersiapkan Ketahanan Keluarga Selama Adaptasi Kebiasaan Baru Di Masa Pandemi Covid-19. Jurnal Kependudukan Indonesia, vol. 2902, pp. 61-68. 2020.

[15] Pusicov. Total Kasus COVID 19 di Kota Bandung. 2020. Diakses pada 21 September 2020 https://covid19.bandung.go.id/

[16] D. Herdiana, Rekomendasi Kebijakan Pemulihan Pariwisata Pasca Wabah Corona Virus Disease 2019 (Covid-19) Di Kota Bandung. Jurnal Master Pariwisata (JUMPA), pp. 1-30. 2020.

[17] Z. Barua, S. Barua, S. Aktar, N. Kabir, and M. Li, Effects of misinformation on COVID-19 individual responses and recommendations for resilience of disastrous consequences of misinformation. Progress in Disaster Science, vol. 8, 100119. 2020.

[18] Law No. 52 of 2009, Perkembangan Kependudukan dan Pendidikan Keluarga

[19] E. Sunarti, Ketahanan Keluarga: Lingkup, Komponen, dan Indikator Semiloka Pengembangan Program Pemberdayaan Dan Ketahanan Keluarga BKKBN. 2011.

[20] E. Sunarti, Motekar (Motivator Ketahanan Keluarga) dan Pemberdayaan Keluarga Rentan. BP3AKB. 2014.

[21] V.R. Hasanah, and D.N. Komariah, MOTEKAR (Motivator Ketahanan Keluarga) dan Pemberdayaan Keluarga Rentan. PAUD Lectura: Jurnal Pendidikan Anak Usia Dini, vol. 2(02), pp. 42-56. 2014.

[22] T.C. Reeves, Enhancing the worth of instructional technology research through "design experiments" and other development research strategies. International perspectives on instructional technology research for the 21st century, vol. 27, pp. 1-15. 2000.

[23] F. Wang, and M.J. Hannafin, Design -Based Reseacrh and TechnologyEnchached Learning Environmental. Journal Educational Technology Research and Development, vol. 54 (4). pp. 5-23, 2005.

[24] S. Barab, and K. Squire, Design-based research: Putting a stake in the ground. The Journal of the Learning Sciences, vol. 13(1), pp. 1-14 2004 